\title{
MODELING VADOSE ZONE CONTAMINANT TRANSPORT AND ROOT SOLUTE UPTAKE IN A PHYTO-EXTRACTION PROCESSES
}

\author{
F. Lugli ${ }^{1}$, C. F. Mahler ${ }^{1}$
}

${ }^{1}$ Department of Civil Engineering, Federal University of Rio de Janeiro (correspondingauthor frlugli@coc.ufrj.br)

\begin{abstract}
Phyto-extraction is an in situ remediation technique involving the uptake of contaminants by plant roots and their subsequent accumulation in plant tissues. It stands out for its simplicity and low costs but nevertheless it is not widely used because of difficulties in estimating its efficiency and the required remediation time. Results depend on a complex set of interactive soil, plant, contaminant and atmospheric processes and parameters. Thus, the objective of this research was to numerically estimate the effectiveness of phytoextraction, varying some project parameters. Remediation of $\mathrm{Cd}^{2+}, \mathrm{Pb}^{2+}$ and $\mathrm{Zn}^{2+}$ contaminants by Chrysopogon zizanioides (Vetiver grass) was simulated using the Hydrus-1D software package. Variably-saturated flow was described using the standard Richards' equation, and solute transport using the advection-dispersion equation. Sink terms in the governing flow and transport equations accounted for root water and solute uptake, respectively. Sorption of metals by the solid phase was described using linear isotherms. Two models for contaminant uptake by the roots were used: passive uptake in which uptake is proportional to the solution concentration, and active uptake as described with a Michaelis-Menten kinetic equation. All the applied models were adjusted on greenhouse remediation experiments in previous study. Dynamic field conditions (data from the coastal lowlands of the municipality of Rio de Janeiro) were considered. Several scenarios were tested, including different planting densities and irrigation schemes. The sensitivity analysis permitted to identify several trends in the simulations. It was found that the efficiency of phyto-extraction decreased significantly when contaminant sorption increased (higher retardation factors). By comparison, phytoextraction was more efficient in time for more mobile contaminants, depending upon the advective contaminant transport velocity in the root zone, the potential transpiration rate, and prevailing water stress conditions in the soil root zone. While more elaborate calibrations may be needed using long-term field data, this study provided useful insight into the phytoextraction process important for the design of future experiments.
\end{abstract}

Keywords: Non-saturated soil, Richard equation, contaminant transport, plant solute uptake 


\section{INTRODUCTION}

Phyto-extraction is a remediation technique based on contaminant uptake by plant roots. Pollutants are generally accumulated in plant tissues. Plant based remediation processes are currently used for many classes of contaminants, including hydrocarbons, pesticides, explosives, metals, radionuclides, chlorinated solvents, and waste landfill leachate. These techniques can be complementary or alternative to chemical and mechanical treatments. Their applicability depends basically on the resistance of the plant to contaminants. In addition, the efficiency of the process depends strongly on the site characteristics such as soil, climate, hydrology and soil-contaminant interactions. Due to this variability, it is difficult to estimate the cost and the time necessary for a phytoremediation project. Some studies[1, 2] show that the costs due to installation, instruments and labor can be significantly lower compared to other techniques.

The present research was focused on numerical modeling of soil-plant-atmosphere continuum, proposing a method for the calculation of:

1. time required for remediation (according to Brazilian Law),

2. efficiency, defined as the ratio between contaminant mass withdrawn from the soil and contaminant mass previously leached into the soil.

The software Hydrus-1D[3] was applied to scenarios of remediation of soil contaminated by metal ions $\left(\mathrm{Cd}^{2+}, \mathrm{Pb}^{2+}\right.$ and $\left.\mathrm{Zn}^{2+}\right)$, using Chrysopogon zizanioides (Vetiver grass). Pedology and climate data were relative to an industrial area of the municipality of Rio de Janeiro. The model parameters, relative to the crop, were determined and calibrated in a previous study, based on greenhouse experiment[4].

\section{MATERIALS AND METHODS}

The Hydrus-1D code uses linear finite element method of Galerkin type for spatial discretization and finite difference method for time discretization of the Richards equation (variably saturated flows). For solute transport, Hydrus-1D is based on the resolution of the advection-dispersion equation by finite elements [3].

The main hypotheses of this study were:

1. one-dimensional approach,

2. absence of preferential flow paths,

3. invariance of the potential root contaminant uptake,

4. remediation process based only on direct extraction of the contaminant,

5. absence of growth, senescence, intoxication phenomena,

6. contaminants are considered separately. 


\subsection{Water uptake model}

Water uptake was calculated by Hydrus-1D, through a macroscopic approach determining the sink term in Richards equation [5, 6]. In this study water stress was considered according to Feddes' formulation[5].

The root water uptake was calculated directly by Hydrus code, through a macroscopic approach determining the sink term in the Richards equation. This term, $s\left[\mathrm{~T}^{-1}\right]$, was calculated from the equation

$$
s\left(h, h_{\phi}, x, t\right)=\alpha\left(h, h_{\phi} x, t\right) b(x, t) T_{p}(t)
$$

where $T_{p}(t)\left[\mathrm{LT}^{-1}\right]$ was the normalized root distribution $\left[\mathrm{L}^{-1}\right]$, a function of space and time (in the case of root growth). The function $\alpha[-]$ represented the response to plant stress $(0 \leq \alpha \leq$ 1), by varying the hydraulic and osmotic head.

\subsection{Contaminant uptake model}

Roots contaminant uptake, when present, was calculated with models defined as passive and active. The first assume that the solute uptake is locally proportional to root water uptake and the concentration of the solute dissolved in water:

$$
p(x, t)=s(x, t) c(x, t)
$$

The active root solute uptake $a(x, t)\left[\mathrm{ML}^{-3} \mathrm{~T}^{-1}\right]$ was calculated using Michaelis-Menten kinetics[7]. The theoretical maximum uptake value was called as potential active solute uptake $A_{p}(t)\left[\mathrm{ML}^{-2} \mathrm{~T}^{-1}\right]$, characteristic of the pair plant-solute (function of time)[8].

$$
a(x, t)=\frac{c(x, t)}{K_{m}+c(x, t)} b(x, t) A_{p}(t)
$$

$K_{\mathrm{m}}$ was defined as Michaelis-Menten constant $\left[\mathrm{ML}^{-3}\right]$. Applied values were $K_{m}=0,09537$ $\mu \mathrm{g} / \mathrm{cm}^{3}$ and $A_{p}=0,0271 \mu \mathrm{g} \cdot \mathrm{cm}^{-2} \mathrm{day}^{-1}$ for $\mathrm{Cd}^{2+} \mathrm{e} K_{m}=1,32 \mu \mathrm{g} / \mathrm{cm}^{3}$ and $A_{p}=0,4757 \mu \mathrm{g} \cdot \mathrm{cm}^{-2} /$ day for $\mathrm{Pb}^{2+}$.

\subsection{Soil}

The soil analyzed is a Halpic Gleysol. In the simulations only the unsaturated zone was modeled. The water table was assumed to have a fixed depth $(90 \mathrm{~cm})$. Two horizons were considered: $A$, clay and $C$, sandy clay loam. The parameters of van Genuchten - Mualem hydraulic model[9] were estimated for each horizon using CalcPTF algorithm (pedotransfert functions)[10]. 
Table 1. Hydraulic parameters of the van Genuchten - Mualem model[9] relative to Halpic Gleysol

\begin{tabular}{crrrrr}
\hline horizon & $\begin{array}{c}\theta_{r} \\
{\left[\mathrm{~cm}^{3} / \mathrm{cm}^{3}\right]}\end{array}$ & $\begin{array}{c}\theta_{s} \\
{\left[\mathrm{~cm}^{3} / \mathrm{cm}^{3}\right]}\end{array}$ & $\begin{array}{c}\alpha \\
{\left[\mathrm{cm}^{-1}\right]}\end{array}$ & $\begin{array}{c}n \\
{[-]}\end{array}$ & $\begin{array}{c}K_{s} \\
{[\mathrm{~cm} / \mathrm{day}]}\end{array}$ \\
\hline $\mathrm{A}$ & 0,1555 & 0,5688 & 0,0654 & 1,1910 & 61,66 \\
$\mathrm{C}$ & 0,0900 & 0,4265 & 0,0450 & 1,3154 & 68,02 \\
\hline
\end{tabular}

\subsection{Boundary conditions}

The top boundary conditions were imposed using daily values of precipitation, potential evaporation and transpiration. The reference evapotranspiration was determined using the equation of Penman-Monteith (version of the Food and Agriculture Organization)[11, 12].

Pressure head $h$ was considered constant and equal to zero at the bottom of the profile.

\subsection{Soil-contaminant interaction}

Ion sorption in soil solid phase was considered using a linear model for both horizons. The distribution coefficients $\left(K_{d}\right)$ were inferred from a study[13] about tropical soils with similar characteristics, using $140 \mathrm{~cm}^{3} / \mathrm{g}, 1500 \mathrm{~cm}^{3} / \mathrm{g}$ and $70 \mathrm{~cm}^{3} / \mathrm{g}$, respectively, for $\mathrm{Cd}^{2+}, \mathrm{Pb}^{2+}$ and $\mathrm{Zn}^{2+}$. Standard values for the diffusion coefficients in free water were applied[14].

\subsection{Simulation phases}

The numerical simulations were organized in three phases: pre-contamination, contamination and remediation. The first phase (one year) was necessary to fix average pressure head profile. The presence of shrubby vegetation was included in the top $B C$.

During the contamination phase, the presence of containers, leaching metal ions in presence of rain, was simulated. It was also estimated that the vegetation suffered degradation due to toxicity of the contaminants. Therefore, transpiration values were considered equivalent to $20 \%$ of the reference. In this phase, no contaminant uptake was considered. The simulated period was of five years.

For remediating the soil, original vegetation was substituted by Chrysopogon zizanioides. According to an experimental study[15], this variety doesn't suffer any toxicity effect at considered concentrations. The Feddes' parameters where estimated by analogy with similar plants from the same family (Poaceae)[16]. The solute uptake model selection and the determination of the relative parameters were performed in a previous study[17]. An active model was used for $\mathrm{Cd}^{2+}$ and $\mathrm{Pb}^{2+}$ and a passive model for $\mathrm{Zn}^{2+}$. The process was considered 
complete when the concentration of each contaminants would be punctually lower than the standard values for industrial areas (Brazilian Law)[18].

\section{RESULTS AND DISCUSSION}

\subsection{Influence of the mobility of the contaminant in soil}

The results of the remediation phase were compared with a no remediation scenario (degraded vegetation). Notable differences emerged, upon changing the behavior of the soil contaminants (Table 2). In the case of lead ion (strongly adsorbed by soil solid phase), cumulative root contaminant uptake was irrelevant to remediation. Considering zinc, less sorbed than lead, remediation time was shorter and natural plume migration was limited by the action of the plants (Figure 1 and Figure 2). Vegetation took up more than $40 \%$ of the contaminant present in the soil. The case of cadmium (Table 2) showed intermediate results.

The evidence showed that more mobile chemical species (which also cause greater environmental concern), had better results in terms of phyto-extraction. On the contrary, more reactive species (high $K_{d}$ ) tended to be "naturally attenuated" but not phytoremediated.

Table 2. Transport and contaminant uptake with and without remediation

\begin{tabular}{llcccc}
\hline test & Ion & remediation & $\begin{array}{c}\text { remediation time } \\
\text { [months] }\end{array}$ & $\begin{array}{c}\text { contaminant } \\
\text { extracted/initial }\end{array}$ & plume depth [cm] \\
\hline 1 & $\mathrm{~Pb}^{2+}$ & yes & 90 & $2,4 \%$ & 12,23 \\
2 & $\mathrm{~Pb}^{2+}$ & no & 90 & $0,0 \%$ & 13,81 \\
3 & $\mathrm{Cd}^{2+}$ & yes & 60 & $10,6 \%$ & 25,42 \\
4 & $\mathrm{Cd}^{2+}$ & no & 48 & $0,0 \%$ & 32,05 \\
5 & $\mathrm{Zn}^{2+}$ & yes & 48 & $41,6 \%$ & 33,17 \\
6 & $\mathrm{Zn}^{2+}$ & no & 52 & $0,0 \%$ & 45,09 \\
\hline
\end{tabular}




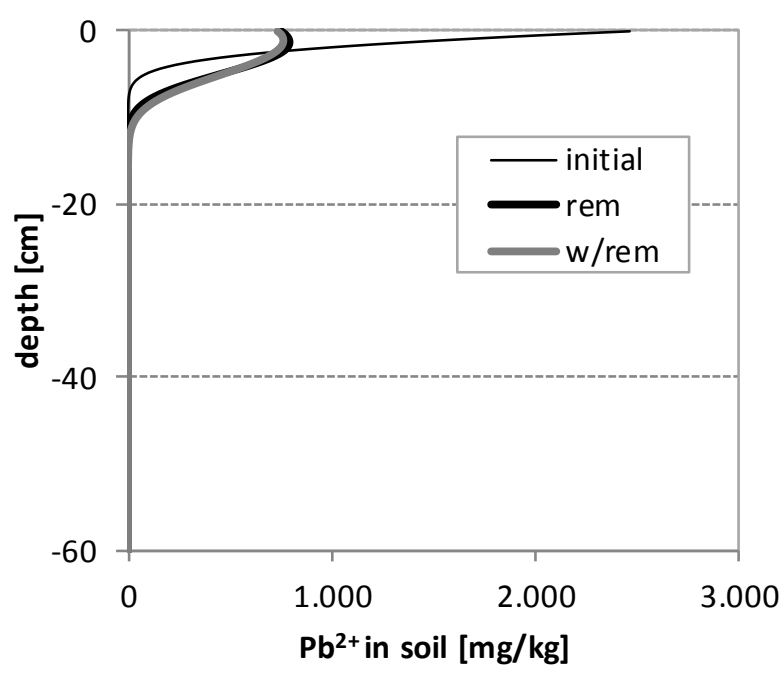

Figure 1: $\mathrm{Pb}^{2+}$ plumes: initial $=$ immediately after contamination; rem $=$ remediation $(1), \mathbf{w} / \mathbf{r e m}=$ without remediation (2), after 10 years

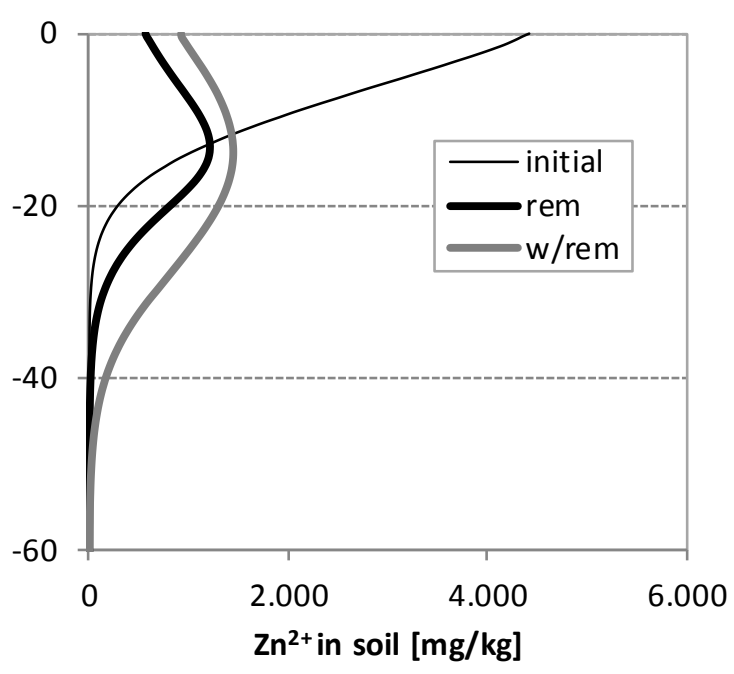

Figure 2: $\mathrm{Zn}^{2+}$ plumes: initial $=$ immed iately after contamination; rem $=$ remediation (5), w/rem $=$ without remediation (6), after 10 years

\subsection{Influence of water balance}

The first six tests (Table 2) were conducted with soil moisture conditions that led vegetation to a mild water stress. In order to test a scenario with a higher root water uptake, and consequently higher contaminant uptake, an irrigation system was virtually activated by a tensiometer placed at $15 \mathrm{~cm}$ depth (irrigation started at wilting point).

Due to a higher water availability, extraction of contaminant increased (Table 3). At the same time, the larger flow through the rhizosphere displaced the contaminant plume downwards.

Table $3 . \mathrm{Zn}^{2+}$ remediation for different hydraulic conditions

\begin{tabular}{llcccc}
\hline test & Hydraulic condition & $\begin{array}{c}\text { Remediation } \\
\text { time [months] }\end{array}$ & Water stress & $\begin{array}{c}\text { Contaminant } \\
\text { extracted/initial }\end{array}$ & $\begin{array}{c}\text { Plume depth } \\
\text { [cm] }\end{array}$ \\
\hline 5 & reference & 48 & $8,9 \%$ & $41,6 \%$ & 33,2 \\
7 & Irrigation (330 mm/year) & 42 & $2,1 \%$ & $42,8 \%$ & 36,6 \\
8 & 5 cm Clay layer & $>120$ & $33,0 \%$ & $33,3 \%$ & 26,3 \\
\hline
\end{tabular}




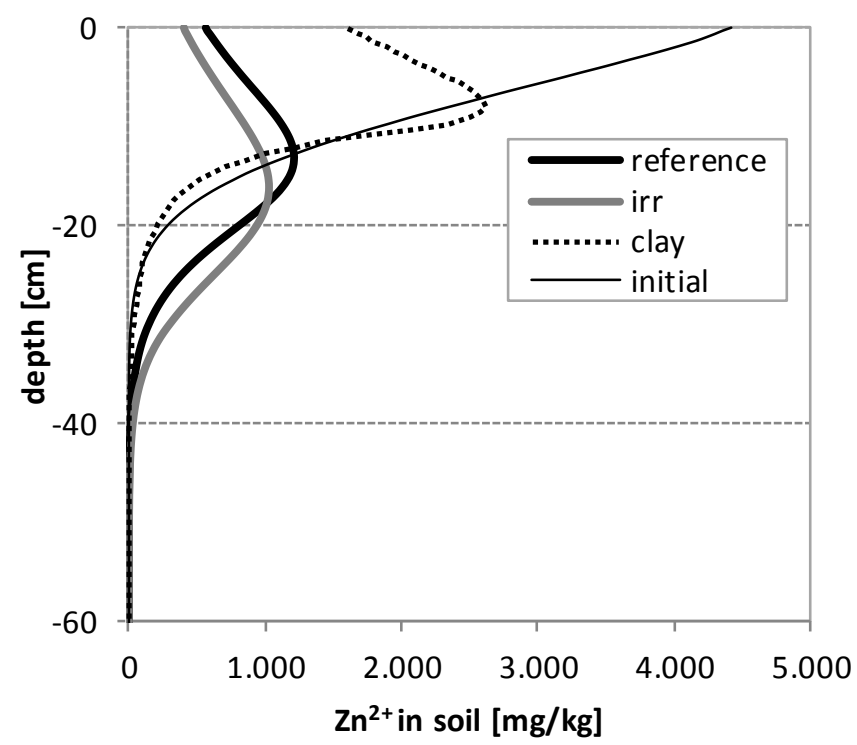

Figure $3: \mathrm{Zn}^{2+}$ plumes: initial = immediately after contamination; rem = remediation $(1)$, $\mathbf{w} / \mathbf{r e m}=$ without remediation (2), after 10 years

\subsection{Influence of the planting density}

Supposing that the Vetiver grass potential evapotranspiration is constant within the range of planting densities considered, the only variable influencing the water demand of vegetation would be the leaf area index (LAI). Thus, in order to study the efficiency of phytoextraction to vary the spacing between the plants, were compared case $5\left(\mathrm{Zn}^{2+}\right)$ where $\mathrm{LAI}=3$, and cases with LAI values corresponding to 2 and 5 .

From point of view of water balance, high values of LAI are related to a significant transpiration activity. Rhizosphere advective contaminant transport is expected to grow as evidenced in test 9 (Table 4) and other numerical studies[17]. According to the tests performed, by increasing the LAI, a diminution of remediation time was also observed (Figure 4).

Since evapotranspiration was considered constant, evaporation lowered. Its effect was completely compensated by a corresponding growth in potential transpiration. Despite of this, there was no appreciable increment of the transport within the rhizosphere.

In addition, the water stress index $\left(1-T / T_{p}\right)$ increased because the soil moisture conditions were not sufficient to compensate the increase of transpiration.

Table $4 . \mathrm{Zn}^{2+}$ remediation for different LAI values

\begin{tabular}{ccccccc}
\hline test & $\begin{array}{c}\boldsymbol{L A I} \\
{[-]}\end{array}$ & $\begin{array}{c}\text { Remediation } \\
\text { time [months] }\end{array}$ & $\begin{array}{c}\boldsymbol{T} \\
\text { [mm/year] }\end{array}$ & Water stress & $\begin{array}{c}\text { Contaminant } \\
\text { extracted/initial }\end{array}$ & $\begin{array}{c}\text { Plume depth } \\
\text { [cm] }\end{array}$ \\
\hline 5 & 3 & 48 & 1192,4 & $8,9 \%$ & $41,58 \%$ & 33,2 \\
8 & 2 & 54 & 985,5 & $6,8 \%$ & $36,26 \%$ & 33,3 \\
9 & 5 & 42 & 1388,9 & $11,4 \%$ & $45,84 \%$ & 33,4 \\
\hline
\end{tabular}




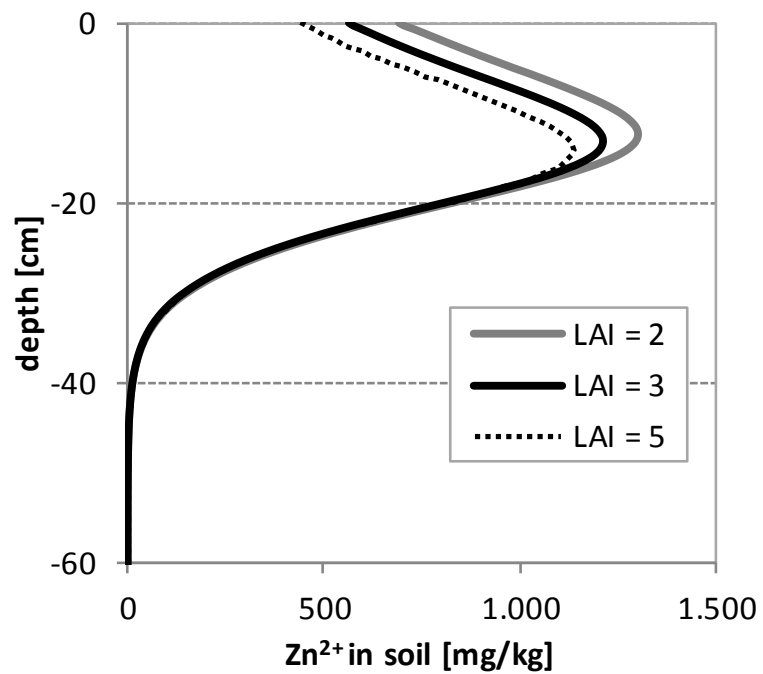

Figure $4: \mathrm{Zn}^{2+}$ plumes for diferent values of LAI, after 10 years of remediation

\section{CONCLUSIONS}

The present study examined the performance of a phyto-extraction process in the presence of metal ions, using numerical modeling. According to the assumptions related to the model and the analyzed scenarios, it was highlighted that, by increasing the fraction of contaminant sorbed on the solid phase, the phyto-extraction process became less efficient. No relevant effects were registered in case of $\mathrm{Pb}^{2+}$ contamination. For contaminants characterized by low retardation factors (e.g. $\mathrm{Zn}^{2+}$ ), the remediation process resulted more efficient.

Moreover, water stress partially inhibited contaminant uptake, but prevented plume migration towards water table. The results also showed that the phyto-extraction process becomes more efficient by increasing the amount of transpiration at the expense of the portion of evaporation (e.g. increased crop density).

As a general consideration, the proposed methodology provided important data for the design and evaluation of a phyto-extraction process.

\section{Acknowledgements}

The authors thank the Institutions of the Brazilian Government CAPES and CNPq for the scholarships. The authors also thank Martinus van Genuchten for the continuous support during this (and previous) researches.

\section{REFERENCES}

[1] ITRC, "Phytotechnology Technical and Regulatory Guidance and Decision Trees, Revised, PHYTO-3". Interstate Technology \& Regulatory Council, Phytotechnologies Team, Tech Reg Update, Washington, D.C., 2009.

[2] Truong P.N.V., Foong Y., Guthrie M., Hung Y.-T., "Phytoremediation of Heavy Metal Contaminated Soils and Water Using Vetiver Grass". in Environmental Bioengineering, Wang L.K., et al., Eds., Humana Press, 233-275, 2010.

[3] Šimůnek J., Sejna M., Saito H., Sakai M., van Genuchten M.T., "The HYDRUS-1D Package for Simulating the Movement of Water, Heat, and Multiple Solutes in 
Variably Saturated Media, Version 4.08". Department of Environmental Sciences, University of California, Riverside, California, USA, 2009.

[4] Lugli F., van Genuchten M.T., Mahler C.F., "Phytoremediation: Simultaneous calibration of contaminant soil sorption and plant uptake". in SETAC Europe 21st Annual Meeting, Milan, 2011.

[5] Feddes R.A., Zaradny H.K., Kowalik P.J., "Simulation of Field Water Use and Crop Yield". New York, NY, USA, John Wiley \& Sons Inc, 1978.

[6] Vogel T., "SWMII-Numerical model of two-dimensional flow in a variably saturated porous medium". Research report nr. 87. Vakgroep Hydraulica en Afvoerhydrologie. LUW (1988) 120 pp., 1988.

[7] Jungk A.O., "Dynamics of nutrient movement at the soil-root interface". in Plant roots: The Hidden Half, Waisel Y., Eshel A., and Kafkafi U., Eds., Marcel Dekker, Inc. New York, 587-616, 2002.

[8] Šimůnek J., Hopmans J.W., "Modeling compensated root water and nutrient uptake". Ecological Modelling, 220(4), 505-521, 2009.

[9] van Genuchten M.T., "A Closed-Form Equation for Predicting the Hydraulic Conductivity of Unsaturated Soils". Soil Science Society of America Journal, 44(5), 892-898, 1980.

[10] Tomasella J., Pachepsky Y., Crestana S., Rawls W.J., "Comparison of two techniques to develop pedotransfer functions for water retention". Soil Science Society of America Journal, 67(4), 1085-1092, 2003.

[11] Allen R.G., Jensen M.E., Wright J.L., Burman R.D., "Operational estimates of reference evapotranspiration". Madison, WI, USA, American Society of Agronomy, 1989.

[12] Allen R.G., Pereira L.S., Raes D., Smith M., "Crop evapotranspiration: guidelines for computing crop water requirements". FAO Irrigation and Drainage Papers, Rome, Italy, Food and Agriculture Organization of the United Nations, 1998.

[13] Soares M.R., "Distribution Coefficient $\left(\mathrm{K}_{\mathrm{d}}\right)$ Of Heavy Metals In Soils Of The State Of São Paulo". PhD Thesis, Agronomy Department, Agriculture School "Luiz de Queiroz" / USP, Piracicaba, São Paulo, 2004.

[14] Shackelford C.D., Daniel D.E., "Diffusion in Saturated Soil .1. Background". Journal of Geotechnical Engineering-ASCE, 117(3), 467-484, 1991.

[15] Tavares S.R.d.L., "Phytoremediation of Soil and Water in Areas Contaminated by Heavy Metals from the Provision of Hazardous Waste". $\mathrm{PhD}$ Thesis, Civil Engineering Department, COPPE / Federal University of Rio de Janeiro, Rio de Janeiro, 2009.

[16] Wesseling J.G., "Meerjarige simulatie van grondwaterstroming voor verschillende bodemprofielen, grondwatertrappen en gewassen met het model SWATRE". Wageningen, DLO-Staring Centrum, 1991.

[17] Lugli F., "Numerical Modeling of Phytoremediation Processes of Soils". M.Sc. Thesis, Civil Engineering Department, COPPE / Federal University of Rio de Janeiro, Rio de Janeiro, 2011.

[18] CONAMA, "Resolução n n 420". Publicação DOU nº 249, do 30/12/2009, 81-84, 2009. 